\title{
PELATIHAN KEMAMPUAN KOMUNIKASI DAN TEKNIK PEMASARAN SERTA PENYUSUNAN BUSINESS PLAN PADA WARGA BELAJAR PKBM INSAN KARYA-TANGERANG SELATAN
}

\author{
Iis Noviyanti *, Antonius Aji Tri Budianto, Udin Ahidin \\ Dosen Fakultas Ekonomi. Universitas Pamulang \\ Email*: noviya.115@gmail.com
}

\begin{abstract}
ABSTRAK
Kegiatan pengabdian kepada masyarakat ini bertujuan untuk memberikan pengetahuan dan keterampilan didalam berkomunikasi dan melakukan pemasaran serta membuat business plan yang baik kepada warga belajar PKB Insan Karya TangerangSelatan.

Pelatihan ini tidak hanya di bimbing oleh mahasiswa namun kami sebagai tim PKM Unpam berusaha untuk mengajak warga belajar PKBM Insan Karya untuk mencipatakan suatu peluang usaha dan memasarkan nya kepada masyarakt baik itu usaha kecil maupun menengah. Metode pengajaran yang diberikan dengan memberikan materi dan teori tentang konsep melakukan komunikasi yang baik didalam meraih pelanggan dan memasarkan produk yang dijual secara benar agar seusai dengan target marketnya.

Pelatihan in diadakan selama dua hari dimana dari hasil pelatihan yang diberikan kepada warga belajar PKBM mengerti tentang komunikasi yang baik dan dapat memahami konsep pemasaran yang benar karena selama proses pelatihan yang diadakan setiap warga belajar diberikan kesempatan untuk mempraktekan usaha-usaha yang dimiliki nya dan rencana usaha yang akan dijalankanya. Dan membuat suatu kerjinan tangan sebagai salah satu contoh dari peluang usaha.
\end{abstract}

\section{Kata Kunci: Keterampilan, Komunikasi, Pemasaran.}

\section{PENDAHULUAN}

Program pengabdian kepada masyarakat merupakan salah satu program yang wajib dilaksanakan, baik oleh dosen maupun oleh mahasiswa, dengan berlandaskan pada prinsip-prinsip: kompetensi akademik, jiwa kewirausahaan (entrepreneurship), dan profesional, sehingga dapat menghasilkan program pengabdian kepada masyarakat yang bermutu, relevan, dan sinergis dalam meningkatkan pemberdayaan masyarakat.

PKBM Insan Karya melibatkan banyak komponen masyarakat untuk menjadi penguat organisasi, sebagai pengajar dan juga sukarelawan. PKBM Insan Karya bersama masyarakat ingin mewujudkan pendidikan nonformal gratis yang dapat merangkul masyarakat menengah ke bawah yang tidak mendapat akses 
pendidikan formal atas berbagai alasan atau pun anak putus sekolah karena kesempitan ekonomi.

Mayoritas warga belajar PKBM Insan Karya adalah masyrakat yang sudah bekerja dan memiliki usaha, sehingga untuk mereka yang sudah memilki usaha di beri pelatihan dan pengarahan agar usaha nya dapat berjalan dengan baik salah satau nya adalh dengan pengarahan berkaitan dengan komunikasi dan teknik atau strategi pemasaranya, sedangkan bagi warga belajar PKBM Insan Karya di motivasi untuk membuka usaha dengan menjelaskan tentang business plan. Maka dari itu setiap jenis usaha baik yang sudah ada atau belum perlu di jalankan dengan baik dan menawarkan produk yang di jual dengan baik hingga terjadi nya permintaan, maka dari itu untuk mengkomunikasikan produk yang akan ditawarkan diperlukan suatu strategi agar komunikasi anatar penjual dan pembeli dapat terjalin dengan baik, banyak orang yang salah kaprah dimana mereka percaya bahwa kegitan komunikasi tidak lebih dari sekedar penyebaran kata dan ilustrasi. Karena prosses komuniasi merupakan sebuah kegiaatan yang bersifat komplek. Interaksi komunikasi dengan seseorang harus memperhatkan bagaiamana karekteristik dari seseorang yang kita ajak biaca tersebut.seperti frame of refrence, pendidikan, sifat dan sebagainya (Rangkuti 2004:48). Didalam menyusun komunikasi pemasaran perlu mempertimbangkan dan memperhitungkan faktor-faktor pendukung maupun penghambat dalam tiap-tiap komponen komunikasi agar proses pemasaran produk yang dijual dapat berjalan dengan baik. Para warga belajar PKBM Insan Karya mayoritas adalah orang yang sudah bekerja dan memiliki usaha diantara nya adalah usaha menjual baju dan bengkel serta counter handphone dan pekerja sebagai marketing.

Kendala yang dihadapi oleh warba belaja PKBM Insan Karya adalah kesulitan untuk melakukan komunikasi baik kepada pembeli ataupun orang lain untuk menawarkan produk yang di jualnya. Selain komunikasi yang baik maka diperlukan teknik pemasaran yang baik. Berhasil tidaknya seseorang didalam memasarkan produk yang dihasilkan baik itu barang maupun jasa sangat dibutuhkan teknik pemasaran yang baik dan tepat, sebab teknik dalam memasarkan sebuah produk meruapakan ujung tombak bagi perusahaan atau wirausahawan dalam mencapai tujuannya. Teknik pemasaran sama saja dengan strategi pemasaran dimana setiap warga belajar PKM Bina Insan yang memiliki usaha pasti mempunyai tujuan agar usaha yang dimiliki nya dapat tetap hidup dan berkembang dimana tujuan tersebut dapat dicapai melalaui usaha mempertahankan dan meningkatkan keuntungan tau laba terhadap usahanya. Tujuan ini dapat dicapai apabila kita dapat melakukan strategi yang baik untuk menggunakan kesempatan atau peluang yang ada dalam pemasaran karena startegi pemasaran merupakan 
serangakaian tujuan dan sasaran, kebijakan dan aturan yang memberi arah kepada usaha pemsaran dari waktu ke waktu pada masing-masing tingkatan dan acuan serta alokasinya terutama sebagai tanggapan perusahaan dalam menghadapai lingkungan dan keasaan persaingan yang selalu berubah, Sofjan Assuari $(2013 ; 15)$.

Selain komunikasi dan teknik pemasaran yang diberikan kepada para warga PKBM Insan maka sasaran berikutnya adalah agar mereka mampu membuat business plan yang berkaitan dengan usaha yang dijalankanya dengan baik karena business plan itu sendiri merupkan suatu dokumen yang menyatakan keyakinan akan kemampuan sebuah bisnis untuk menjual barang atau jasa dengan menghasilkan keuntungan yang memuaskan dan menarik bagi penyandang dana, Bygrave (1994:114). Sasaran kegiatan pengabdian kepada masyarakat (PKM) ini adalah dengan mengajak warga belajar PKBM Insan Karya dan mahasiswa universitas pamulang untuk mengikuti Pelatihan Kemampuan Komunikasi Dan Teknik Pemasaran Serta Penyusunan Business Plan Pada Warga Belajar PKBM Insan Karya-Tangerang Selatan.

\section{RUMUSAN MASALAH}

Dari latar belakang masalah tersebut maka dapat dirumuskan permasalah yaitu bagaimana tigkat pengetahuan dan keterampilan didalam berkomunikasi dan melakukan pemasaran serta membuat business plan yang baik kepada warga belajar PKB Insan Karya Tangerang-Selatan?

\section{TUJUAN}

Sedangkan tujuan yang ingin dicapai dalam kegiatan ini adalah : Untuk mengetahui tigkat pengetahuan dan keterampilan didalam berkomunikasi dan melakukan pemasaran serta membuat business plan yang baik kepada warga belajar PKB Insan Karya Tangerang-Selatan

\section{KEGIATAN}

Sasaran dari program in Pengabdian Masyarakat yang akan kami lakukan ini adalah warga belajar PKBM Insan Karya. Jln. Haji Saleh, No. 42.RT. 05.RW.02, Benda Baru, Pamulang, Tangerang Selatan. 14516,pkbminsankarya.blogspot.co.id.

Jumlah peserta pelatihan kurang lebih 50 orang, yang terdiri dari warga belajar, program paket $\mathrm{A}$, program paket $\mathrm{B}$, program paket $\mathrm{C}$, dan Program Keaksaraan. Adapun pelaksanan dari kegiatan adalah sebagai berikut:

Hari

: Selasa s/d Rabu

Tanggal/Bulan $\quad: 14$ s/d 15 November 2017

Waktu : Pukul $09.00-14.00 \mathrm{WIB}$ 
Tempat

: PKBM Insan Karya. Jln. Haji Saleh, No. 42.RT. 05.RW. 02, Benda Baru, Pamulang.Tangerang selatan. 14516

\section{APLIKASI}

Globalisasi telah mendorong beberapa perusahaan untuk memasarkan di luar negara asal mereka.Pemasaran internasional merupakan bagian dari strategi pemasaran perusahaan-perusahaan tersebut. Manajer pemasaran sering bertanggung jawab untuk mempengaruhi tingkat, waktu, dan komposisi permintaan pelanggan. Hal itu berlaku tidak pada semua kasus karena peran seorang manajer pemasaran dapat bervariasi sangat signifikan berdasarkan ukuran bisnis, budaya organisasi, dan konteks industri. Sebagai contoh, dalam sebuah perusahaan produk konsumen besar, manajer pemasaran dapat bertindak sebagai manajer umum dari keseluruhan produk yang menjadi tugasnya Untuk menciptakan strategi manajemen pemasaran yang efektif dan efisien, perusahaan harus memiliki pemahaman mendetail dan objektifmengenai bisnis mereka sendiri dan pasar tempat mereka beroperasi. Dalam menganalisis permasalahanpermasalahan ini, bidang manajemen pemasaran sering tumpang-tindih bidang.

Dalam menjalankan usaha, ada hal yang lebih penting dibanding menciptakan produk, yaitu pemasaran produk dan jasa yang dilakukan dengan handal. Bisa dikatakan, strategi pemasaran merupakan kunci berhasilnya penjualan suatu produk. Akan tetapi kualitas produk juga tetap perlu diperhatikan karena menjadi poin penting dalam pemasaran tersebut. Setelah memastikan produk yang akan dijual memiliki kualitas yang baik, ciptakanlah strategi pemasaran yang baik dan efektif agar prosesnya dapat berjalan dinamis dan terkontrol. "Strategi Pemasaran adalah pola pikir pemasaran yang akan digunakan untuk mencapai tujuan pemasarannya. Strategi pemasaran berisi strategi spesifik untuk pasar sasaran, penetapan posisi, bauran pemasaran dan besarnya pengeluaran pemasaran." Philip Kotler ( 2004:81). Berikut ini adalah 5 strategi pemasaran dalam berbisnis yang bisa anda terapkan untuk meningkatkan penjualan produk atau jasa yang kita jual:

\section{a. Mengenali Pelanggan}

Lakukan identifikasi terhadap target pasar kita, msalnya, jika usaha kita bergerak dalam pemasaran fashion Korea, kita bisa membidik kalangan remaja yang identik dengan demam Korea. Jika usaha kita bergerak dalam pemasaran sepatu wedges, anda bisa membidik para wanita dengan rentang umur 20-35 tahun. Identifikasi yang tepat dapat mempermudah kita dalam menyusun strategi pemasaran yang efektif dan menghindarkan kita dari pembuangan biaya dan waktu yang sia-sia. 


\section{b. Melakukan Promosi}

Lakukan pengenalan produk/promosi kepada konsumen dengan cara yang kreatif. Sebisa mungkin, kita harus melakukan promosi yang konsisten dan terus-menerus. Misalnya setiap kali kita bepergian, kita bisa membawa brosur dan pamflet berisi produk usaha kita untuk dibagikan kepada orang yang dituju, keluarga, rekan kerja, ataupun disebarkan di tempat-tempat umum. Bisa juga dengan membuat status mengenai produk usaha kita di sosial media. Selain itu, amatilah bagaimana promosi yang diterapkan oleh para kompetitor. Jika promosi kita lebih menarik, silahkan melanjutkan. Namun jika promosi kompetitor jauh lebih menarik, segera siapkan promosi yang lebih unik, kreatif, dan menarik. Satu lagi cara promosi yang dapat kita lakukan adalah dengan berpromosi dari mulut ke mulut. Tak dapat dipungkiri bahwasannya cara ini dapat menjaring pelanggan jauh lebih banyak. Dengan berbagai cara ini, anda dapat menemukan pelanggan dengan sendirinya.

\section{c. Memilih Lokasi yang Strategis}

Hal penting lainnya yang harus diperhatikan ialah pemilihan lokasi usaha. Kita bisa melihat contohnya lewat berbagai Bakery yang berdiri di sepanjang jalan yang sibuk dan dilalui oleh banyak orang. Dan pemilihan lokasi tersebut merupakan salah satu strategi mereka untuk menjaring pelanggan. Karena itu, pilihlah lokasi usaha yang strategis dan tepat agar usaha kita dapat dijangkau oleh pelanggan.

\section{d. Menggunakan Internet Marketing}

Salah satu strategi pemasaran yang sedang gencar dilakukan ialah internet marketing. Dengan menampilkan produk usaha kita pada situs jejaring sosial, maka kita dapat mengetahui bagaimana selera konsumen dan apa yang mereka butuhkan. Semakin hari aktivitas jual beli melalui online shop semakin marak dilakukan. Karena para konsumen cenderung ingin berbelanja dalam ruang yang lebih privat dan terhindar dari keramaian. Internet membuka pintu yang lebar bagi kita untuk berinovasi. Kita dapat menampilkan produk usaha kita pada website, blog, facebook, dan situs lainnya, dengan memasang foto-foto yang sekiranya dapat menarik konsumen. Dengan menggunakan internet marketing, anda juga dapat berinteraksi secara langsung dengan konsumen tanpa dibatasi ruang dan waktu. Salah satu wadah untuk memaksimalkan pemasaran produk atau jasa kita adalah melalui sosial media, khususnya Facebook. Sudah banyak sekali 
pelaku usaha dan pebisnis muda menggunakan Facebook untuk meledakkan penjualan produk atau jasa mereka, selain Facebook yang sekarang sedang upadate adalah instagram karena medsos tersebut sedang banyak digunakan oleh masyrakat.

\section{e. Menjalin Hubungan yang Baik dengan Konsumen}

Konsumen ialah raja. Slogan satu ini patut dipertahankan guna menjaga kelangsungan suatu usaha. Jalinlah hubungan yang baik dengan konsumen. Hubungi mereka untuk sekadar menanyakan testimoni mengenai produk usahakita ataupun menginfomasikan produk yang baru kita keluarkan, dan promo yang sedang berjalan. Karena konsumen membutuhkan produk dan kita membutuhkan konsumen untuk orientasi keuntungan. Maka itu, terapkanlah simbiosis mutualisme dalam hal berbisnis. Menjalin hubungan yang baik dengan konsumen merupakan kunci terakhir yang harus anda pegang untuk mencapai kesuksesan dalam berbisnis.

Selaian strategi atau teknik pemasaran yang baik maka diperlukan komunikasi yang baik juga agar tercapai tujuan didalam memasarkan produk yang dijualnya. Karena pada dasarnya komunikasi adalah proses penyampaian informasi, perintah dan ide dari seseorang kepada orang lain agar diantra mereka terdapat interkasi. Komunikasi pemasaran menurut Kotler dan Keller (2012:498) sarana dimana perushaan menginformasikan, membujuk, dan mengingatkan konsumen secara langsung maupun tidak langsung tentang produk yang mereka jual. Agar suatu esan dapat efektif maka proses pengiriman harus berhungan langusng dengan penerima pesan dimana pesan terbaik adalah pesan yang disamapaikan dengan tanda-tanda yang dikenali oleh penerima pesan apabila pengirim memiliki persamaan pengalaman dan penerima pesan maka komunikasi yang dilakukan akan lebih efektif.

Hubungan antara pemasaran dengan komunikasi merupakan hubungan yang erat. Komunikasi merupakan proses dimana pemikiran dan pemahaman disampaikan antar individu, atau antara perusahaan dan individu. Komunikasi dalam kegiatan pemasaran bersifat kompleks, tidak sesederhana seperti berbincangbincang dengan teman atau keluarga. Bentuk komunikasi yang lebih rumit akan mendorong penyampaian pesan oleh komunikator pada komunikan, melalui strategi komunikasi yang tepat dengan proses perencanaan yang matang. 
Cara mengkomunikasikan informasi dengan efektif sehingga dapat dengan cepat samapai ke calon kosumen ada beberapa hal yang harus di perhatikan dianataranya :

\section{a. Buat pesan yang sederhana.}

Pilihan bahasa dan kalimat yang sederhana akan mempercepat pemahaman dari target yang kita tuju. Seperti pemilihan slogan yang simple dan dapat dengan cepat di ingat oleh konsumen akan membuat produk yang kita tawarkan terus berada dalam benak konsumen.

\section{b. Fokuskan dengan gaya hidup calon pelanggan.}

Dengan mengetahui gaya hidup atau sifat calon konsumen kita, ini akan mempermudah kita dalam menentukan bahasa, gaya dan strategi promosi kita.

\section{c. Tonjolkan nilai produk yang kita tawarkan.}

Semua produk memang selalu ditawarkan sebagai produkk yang nomor satu, tetapi yang saya maksud disini adalah menonjolkan nilai produk yang kita tawarkan di bandingkan produk sejenis. Jangan terlalu mengumbar pesan secara teknis karena itu akan membuat target konsumen kita mengerucut atau menyempit.

\section{d. Ceritakan pengalaman orang lain.}

Pengalaman orang lain kita butuhkan sebagai pendukung testemoni, bahwa produk kita memang layak pergunakan atau di konsumsi.

\section{e. Pergunakan kalimat yang menyentuh .}

Pemilihan kalimat yang menyentuh, berarti kita harus membuat pesan yang dapat membujuk konsumen untuk membeli produk kita, ini berarti pilihan kata dan kalimat harus menghasilkan pesan yang komunikatif, dapat memberikan semangat, membujuk dan menggembirakan dan bahkan memotivasi. Terus lakukan komunikasi dengan mereka agar kita menerima informasi dari calon pelanggan mengenai persepsi mereka terhadap produk kita.

Dengan komunikasi yang efektif dan jelas, akan membuat pesan yang kita sampaikan dapat dengan cepat diterima dan dimengerti oleh konsumen, dan akhirnya akan terbentuk persepsi yang positif terhadap produk yang kita tawarkan. Jika teknik pemasaran dan komunikasi sudah berjalan dengan baik maka usaha 
yang kita miliki dapat berkembang dengan baik maka dari itu kita perlu membuat suatu business plan tentang usaha yang dijalankan agar kedepanya dpaat berjalan dengan baik dan berkembang. Business plan merupakan sebuah pernyataan atau dokumen tertulis yang memuat berbagai hal yang relevan dan mempengaruhi kegiatan bisnis dengan objektif. Adapun yang dibahas adalah tujuan atau visi bisnis, bagaimana nantinya kegiatan operasional dijalankan, rincian mengenai keadaan finansial, status kepemilikan maupun struktur manajemen yang nantinya akan dibuat termasuk pula bagaimana target dan harapan untuk menjadikan tujuan dan target tersebut menjadi nyata (Meggison, 2000). Dalam dunia bisnis, business plan bukan hanya rencana yang dibayangkan di dalam akal. Lebih khusus lagi, bisnis plan merupakan pedoman tertulis yang menggambarkan rancangan - rancangan bisnis dari awal berdiri hingga mengarah pada evaluasi bisnis. Jadi Business Plan adalah dokumen tertulis yang disiapkan oleh wirausaha yang menggambarkan semua unsur yang relevan baik internal maupun eksternal mengenai perusahaan untuk memulai pada waktu usaha. Adapun isinya sering merupakan perencanaan terpadu menyangkut pemasaran,permodalan,operasional dan sumber daya manusia. Fungsi dan Tujuan Utama Business Plan:

a. Merencanakan tujuan utama perusahaan yang akan dicapai baik jangka pendek maupun jangka panjang.

b. Perencanaan Metode dan Strategi yang ditempuh perusahaan untuk meningkatkan daya saing dan produktifitas.

c. Sebagai alat pengawasan dan pengendalian kegiatan usaha.

d. Memberikan gambaran umum kepada investor tentang kondisi perusahaan saat ini dan periode yang akan datang berdasarkan data aktual sehingga memberikan keyakinan kepada mereka tentang seberapa besar tingkat keuntungan dan nilai resiko terhadap investasi.

Sedangakn langkah-langkah menulis business plan yang baik adalah:

\section{a. Langkah 1: Mengenal Bisnis Anda}

Pelajari dan pahami secara menyeluruh dan mendalam mengenai bentuk, potensi dan segala tantangan yang ada pada bisnis Anda. Dalam tahap ini Anda bisa menggunakan teknik analisa SWOT yang telah kita bahas 
sebelumnya. Anda bisa mempelajari hal-hal terkait bisnis ini dengan banyak cara seperti membaca buku dan referensi lain, bertanya dan berdiskusi pada ahli atau orang yang telah melakukannya sebelum Anda dan lainnya.

\section{b. Langkah 2: Tentukan Visi Dalam Business Plan}

Visi merupakan pandangan jauh tentang tujuan dan sasaran perusahaan memang harus dimiliki seluruh pebisnis skala besar hingga skala kecil. Dengan adanya visi yang jelas, maka Anda tak akan kesulitan nantinya dalam merancang alur dari rencana bisnis Anda. Nyatakan visi bisnis dan perusahaan Anda dengan bahasa dan kalimat yang jelas dan mudah dimengerti oleh orang lain.

\section{c. Langkah 3: Tentukan Audiens Anda}

Target audiens yang tepat, maka Anda bisa menyesuaikan konten business plan Anda dengan baik dan benar. Misalkan business plan untuk investor, maka Anda harus menyusun rencana bisnis tersebut dengan lebih serius, mendalam dan profesional.

\section{d. Langkah 4: Tuliskan Rencana Bisnis Anda}

1. Pernyataan Misi. Jelaskan satu hingga tiga paragraf singkat berisi misi dan tujuan bisnis Anda, tuliskan pula prinsip-prinsip yang dianut bisnis Anda serta menyatakan keunikan atau unique selling point (USP) yang membedakan antara perusahaan atau bisnis Anda dengan perusahaan lain yang bergerak di bidang yang sama.

2. Ringkasan Efektif. Tulislah sebuah ringkasan singkat satu sampai dua halaman dari bisnis Anda. Dengan adanya ringkasan, maka pembaca termasuk investor akan dimudahkan untuk melihat potensi bisnis Anda dengan cepat dan efektif. Sebaliknya, tanpa ringkasan, pembaca akan cepat merasa bosan dan jenuh.

3. Penawaran Produk atau Jasa. Tulis deskripsi produk atau jasa yang Anda tawarkan lengkap dengan harga yang Anda jual. 
4. Target Pasar. Jangan lupa juga untuk menuliskan target atau segmentasi pasar yang akan Anda sasar pada bisnis Anda. Tunjukkan bagaimana target pasar Anda akan membeli apa yang Anda tawarkan.

5. Marketing Plan. Tuliskan pula rencana atau strategi pemasaran bisnis pada business plan Anda. Jelaskan secara rinci bagaimana biaya pemasaran, alasan pemilihan strategi pemasaran serta target capaian dari strategi pemasaran tersebut.

6. Analisis Industri dan Tingkat Persaingan.Tuliskan analisis yang lengkap dan menyeluruh terhadap bidang bisnis Anda berserta kompetisi atau tingkat persaingan dari bisnis Anda.

7. Laporan Keuangan. Hal ini berisi tentang apapun terkait pembiayaan atau modal serta pendapatan yang ada pada bisnis Anda. Jika bisnis Anda telah berjalan beberapa tahun, maka cantumkan saja laporan keuangan neraca, laba rugi, arus kas, dan perubahan modal dari bisnis Anda kepada calon investor.

8. Resume of Company Principal. Penjelasan tentang struktur karyawan di perusahaan Anda juga bisa Anda tulis. Sertakan biografi dan latar belakang profesional dari semua karyawan yang signifikan dalam bisnis Anda.

9. Penawaran Anda. Tulislah penawaran serta paket-paket investasi yang Anda miliki pada calon investor.

10. Lampiran

Business Plan yang baik adalah berisikan informasi yang jelas dan mudah dipahami oleh pihak internal maupun eksternal perusahaan mengenai rencana kerja, target perusahaan untuk masa yang akan datang, evaluasi terhadap kinerja usaha yang telah dicapai, serta rencana investasi serta sumber permodalan untuk ekspansi usaha. 


\section{METODE PELAKSANAAN}

Pelaksanaan program pelatihan kemampuan komunikasi dan teknik pemasaran serta penyusunan business plan pada warga belajar PKBM Insan Karya-Tangerang Selatan, melalui tahapan sebagai berikut : identifikasi subjek untuk dilakukan penyuluhan, penyuluhan dan pengenalan serta potensi usaha yang baik dan berkomunikasi yang baik serta strategi pemasaran agar tercapai target penjualan.

\section{PENUTUP}

Dengan ada nya kegiatan ini menjadikan para ibu rumah tangga di lingkungan Pelaksanaan kegiatan pengabdian masyarakat oleh lembaga penelitian dan pengembangan masyarakat (LPPM) Universitas Pamulang yang dilakukan oleh dosen-dosen program studi manajemen telah berjalan dengan lancar dan mendapat sambutan hangat dari tempat pelaksanaan kegiatan ini yaitu Warga Belajar PKBM Insan Karya.

Dan selama kegiatan berlangsung perserta pelatihan memberika tanggapan yang baik, hal ini dpat dilihat dari dukungan mekereka dalam setiap kegiatan yang kami adakan dan hampir disetiap kegiatan warga PPKBM Insan Karya meluangkan waktu untuk berbincang-bincang terkaiat program kami dan usaha yang dimilki atau yang ingin membuka usaha. Selain itu harapan kami dengan pengabdian ini dapat membuka wawasan dari warga belajar PKBM Insan Karya yang kami berikan pelatihan dan praktek dalam bidang pemasaran khusus nya dpaat membuka usaha baru dan meningkatkan usaha yang sudah ada dengan mengelola nya dengan baik agar tercapai target yang diinginkanya.

\section{DAFTAR PUSTAKA}

Assauri, Sofjan. 2013. "Manajemen Pemasaran". Jakarta : Rajawali Pers.

Freddy Rangkuti, 2004. "The Power Of Brands". PT Gramedia Pustaka Utama. Jakarta.

Kotler, Philip. 2004. "Manajemen Pemasaran: Analisis, Perencanaan, implementasi dan Kontrol". Edisi Sebelas. Alih Bahasa, Hendra Teguh. Jakarta: Penerbit PT. Prenhallindo.

Ppti.or.id. 2017. "Langkah-langkah menyusun business plan". Sumber: http://ppti.or.id/2017/01/langkah-penting-menyusun-business-plan-yangbaik/. Diakses Tanggal 18 November 2017.

Sarjanaku.com. 2013. "Pengertian Startegi pemasanran". Sumber: http://www.sarjanaku.com/2013/04/pengertian-strategi-pemasarandefinisi.html. Diakses Tanggal 17 November 2017.

Wikipedia. 2017. "Pengertina Manajemen Pemasaran". Sumber: https://id.wikipedia.org/wiki/Manajemen_pemasaran. Diakses Tanggal 17 November 2017. 
DOKUMENTASI FOTO KEGIATAN
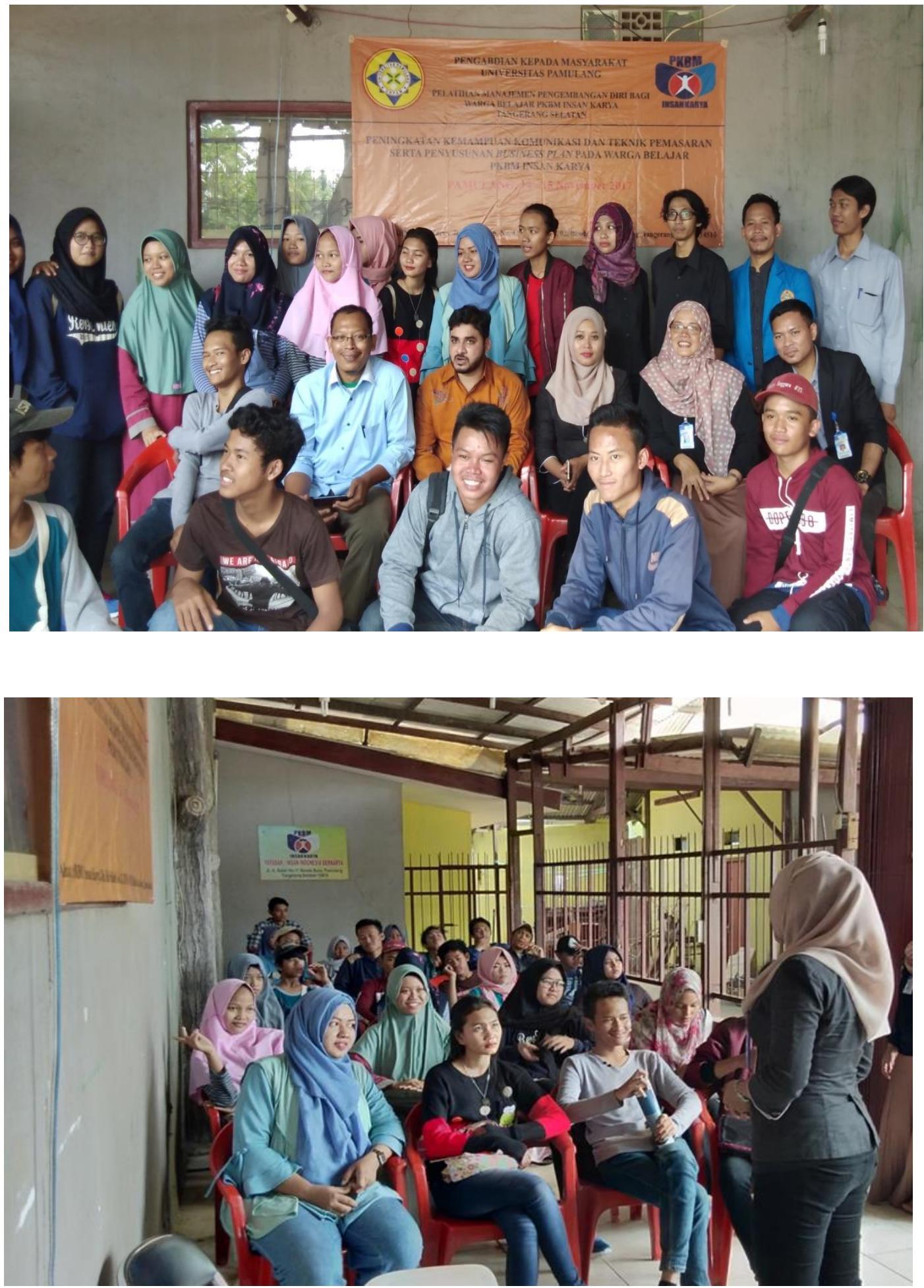